\title{
THE RELATIONSHIP BETWEEN NORMALIZED DIFFERENCE VEGETATION INDEX AND CANOPY TEMPERATURE THAT AFFECTS THE URBAN HEAT ISLAND PHENOMENON
}

\author{
Tissadee PROHMDIREK ${ }^{1}$ (D) Poramate CHUNPANG ${ }^{1}$ (D), Teerawong LAOSUWAN ${ }^{*}$ (iD
}

DOI: $10.21163 / G T \_2020.152 .21$

\begin{abstract}
:
The objective of this research is to analyze the relationship between Normalized Difference Vegetation Index (NDVI) and canopy temperature that affects the Urban Heat Island (UHI) phenomenon in Mueang Maha Sarakham Municipality. The operational methods were divided into three main steps: 1) Analyzing NDVI by using Landsat 8 OLI satellite data 2) Monitoring canopy temperature with mobile traverses installed with digital thermometer and auto-record GPS receiver 3) Analyzing the relationship between NDVI and canopy temperature that passed through the spatial interpolation process using the kriging method. The results of the operational methods indicated that the trend of average atmospheric temperature in the urban area was higher than the outer area. Mueang Maha Sarakham Municipality had the highest UHI in the atmosphere at $4.65^{\circ} \mathrm{C}$. And from the buffer zone with a distance of $800 \mathrm{~m}$ around the centroid point, the highest UHI in the atmosphere was $5.08^{\circ} \mathrm{C}$. From the regression analysis between NDVI and the atmospheric temperature, it could be found a negative relationship between the data with a significance level of 0.01 and the decision coefficient $\left(\mathrm{R}^{2}\right)$ of 0.9392 . This can be explained that if the area from the buffer zone decreased towards the centroid point, the value of NDVI decreased as well. In addition, when the equation set from the regression analysis was brought to predict the difference in atmospheric temperature in the area of Mueang Maha Sarakham Municipality and the surrounding area, the UHI sizes at all periods (16.00$20.00 \mathrm{hrs}$.) increased in accordance with the decreases of NDVI values. Meanwhile, considering the tendency between the changes in UHI size in the atmosphere in each period and NDVI values with the polynomial regression analysis (degree 4), it was found that the maximum formation of UHI was during 18.00-19.00 hrs.'. The decreases in NDVI values resulted in a higher UHI size in each period. In addition, when the NDVI values in Mueang Maha Sarakham Municipality were less than 0.302, the largest size of UHI in the atmosphere will change at the time approaching $19.00 \mathrm{hrs}$.
\end{abstract}

Key-words: Normalized Difference Vegetation Index (NDVI); Urban Heat Island (UHI); Remote Sensing; Landsat 8.

\section{INTRODUCTION}

At present, the rapid development progress in urban areas for human economic prosperity, namely business areas, industrial areas and famous educational centers, has resulted in increasing demand for land uses, especially in central cities or prosperous places with a high population density, for the purposes of operations or performing activities. These land uses have led to the increase in instructions of buildings and roads that affects the changes in environment and atmospheric temperature continuously (IPCC, 2019). This is because, if buildings are exposed to sun heat during daytime, the heat will be released into the atmosphere after sunset. For this reason, when comparing between urban areas and rural areas that are nearby each other, it can be seen that the atmospheric temperature after sunset in urban areas is still higher than rural areas (Huang \& Lu, 2017), which caused occurrence of the Urban Heat Island (UHI) phenomenon in the atmosphere with a tendency of rising temperature from surrounding areas to the highest temperature in central cities (United States Environmental Protection Agency, 2008). Generally, the atmospheric temperature will drop sharply after sunset in rural areas due to most of rural areas or suburbs have more vegetation cover than urban

\footnotetext{
${ }^{1}$ Department of Physics, Faculty of Science, Mahasarakham University, Maha Sarakham, 44150, Thailand

${ }^{*}$ Corresponding author email: teerawong@msu.ac.th
} 
areas. By comparison, during a day, the UHI's size will emerge distinctly after sunset. And during different seasons, the UHI's size will emerge distinctly during the winter (Yokobori \& Ohta, 2007; Singhachantra, 2012).

The result of the increase in land uses is one of the causes that decreases in the amount of vegetation and land covers, that are green space (Zhang et al., 2010; Mathew et al., 2017; Ursu, 2019). Vegetation and green space can help reduce air temperature or the rate of UHI formation in urban areas effectively from water release of trees (Kophim, 2013), including reduction of flux values and heat radiation of buildings that accumulate heat energy from solar radiation throughout daytime, will result in the change in atmospheric temperature after sunset (Takebayashi \& Moriyama, 2009; Perini \& Magliocco, 2014; Yang et al., 2018). According to the previous cause, some periods of time, air temperatures between urban areas and surrounding areas are not balanced. Generally, considering the changes in air temperature at different time periods in the study area, the actual data from ground measurement stations can be analyzed by spatial analysis interpolation in order to predict the quality value trend of the atmospheric temperature in the areas or positions between the points that have the actual measurement data from measurement stations (Gopal \& Kaufmann, 2000; Kambi et al., 2018) in order to obtain the actual air temperatures from measurement stations which have the number of sample points spread as much as possible in the study area. From the study of related documents, it has been found that there are many researchers conducted the measurement of the air temperature by using mobile traverses. The sample points were collected the data continuously along the routes in the study area. Also, locations and air temperatures were automatically recorded. The height of each temperature measurement point was set at 1.5 meters above the earth ground. And the resolution of the measurement tool was generally set at $0.1^{\circ} \mathrm{C}$. The data obtained from the measurement were brought to evaluate and compare the air temperatures around outer areas with urban areas (VicenteSerrano et al., 2005; Sodoudi et al., 2014; Cardoso \& Amorim, 2018) that led to the study of UHI occurrence in the canopy atmosphere, which is a change in the levels of height from the ground in several time periods or areas with a large numbers of living creatures (Dupont \& Ching, 2004; Srivanit \& Hokao, 2012; Mukhelif et al., 2016).

Many researchers had analyzed the relationship of air or surface temperature changes from the UHI phenomenon and land covers by classifying land cover types using remote sensing technology in order to detect vegetation-covered areas or green spaces, buildings, constructions and so on. For example, the study relationship of land surface temperature changes from the UHI phenomenon and the percentage of green spaces was studied by calculating the data from the QuickBird, SPOT, Landsat 5 TM satellite in Beijing, China. The result was found that the green spaces in the range of 10-20\% resulted in the increase in land surface temperature approximately $31-35^{\circ} \mathrm{C}$. If the percentage of vegetation cover increases, the trend of land surface temperature will decrease in accordance with a linear regression relationship ( $\mathrm{Li}$ et al, 2013). From several researches, there are studies and testing the relationship with regression analysis between UHI size and NDVI of areas in Delhi and Mumbai, India in 2010. The results indicated that the relationship between those values had a negative direction and tendency. The thermal expansion revealed that the covers of buildings and bare soils indicated high air temperatures. While areas covered with vegetation and water sources indicated lower air temperatures. The areas that represented the UHI sizes clearly could be found to be the areas densely covered by buildings (Grover \& Singh, 2015). In addition, the Landsat 8 satellite data were used to analyze the expansion of UHI sizes in Skopje, Macedonia area which had the change of land covers over the period of 5 years from 2013 - 2017. The results indicated that the NDVI values decreased while buildings increased from to the expansion of urban area. The thermal expansion showed the highest land surface temperature that changed from the original temperature at $12^{\circ} \mathrm{C}$. This result was consistent with the data of the air temperature change from the weather station of Meteorological Department. And the UHI size expanded from the original area approximately $4 \mathrm{~km}^{2}$ (Kaplan et al, 2018). According to the increase in the temperatures in urban areas as previously mentioned, this research aims to analyze the relationship between NDVI and canopy temperature that affects the UHI phenomenon in Mueang Maha Sarakham Municipality, that will lead to the assessment of the changed relationship of vegetation and UHI sizes. 


\section{MATERIALS AND METHODS}

Mueang Maha Sarakham Municipality, Talat District, Maha Sarakham Province (Fig. 1) has an

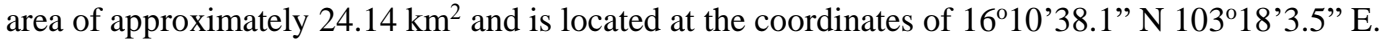

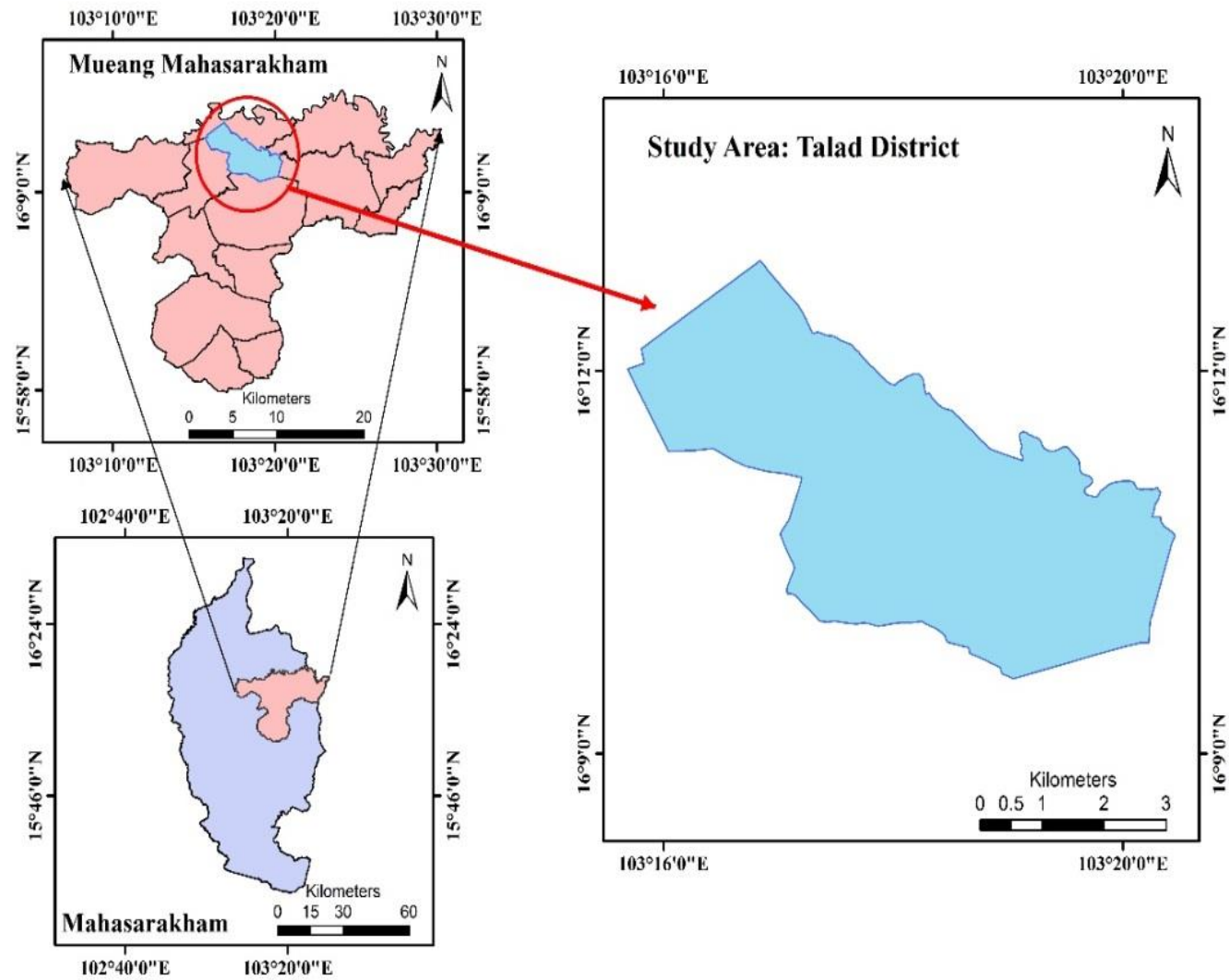

Fig. 1. Study area.

The characteristic of the area is an anticline highland. The general area is approximately 130-230 meters above sea level. According to the data of 2009, the population in Mueang Maha Sarakham Municipality was a total of 39,965 people with a population density of 1,655 people $/ \mathrm{km}^{2}$ and 16,759 households. In 2019, the population density increased to 2,124 people $/ \mathrm{km}^{2}$ and the housing rate increased up to 62\% (Official Statistics Registration Systems, 2019). This represented that the area of Maha Sarakham Municipality had an expansion of population due to it has played an important role in being a central city for educational services. Moreover, according to the data from Meteorological Department, the average annual temperature was $33.4^{\circ} \mathrm{C}$ in 2019 (Thai Meteorological Department, 2019).

\subsection{Surveying the study area}

Studying the routes along the road network in the study area as well as exploring the actual area in order to set a route for the optimal period for collecting sample data and covering the study. In this study, the routes for collecting data in the study area were divided into 2 parts (Fig. 2) including inner routes and outer routes of Mueang Maha Sarakham Municipality. 


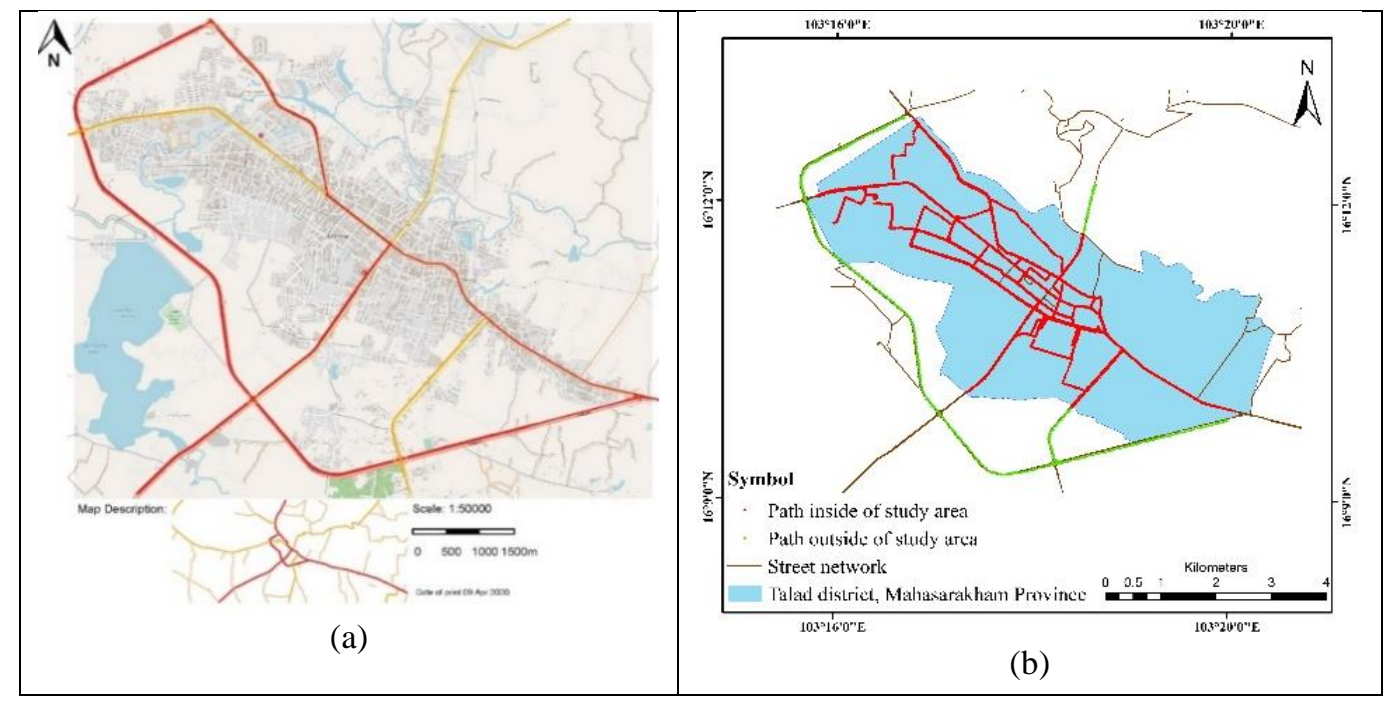

Fig. 2. (a) Road network covering the study area, (b) Path to store sample data inside and outside Mueang Maha Sarakham Municipality.

\subsubsection{Conditions and data collection periods}

This research collected the sample data during the winter in February 2020. The periods of days were $16.00 \mathrm{hrs}$., $17.00 \mathrm{hrs}$., $18.00 \mathrm{hrs}$., $19.00 \mathrm{hrs}$. and $20.00 \mathrm{hrs}$. due to the UHI phenomenon in the atmosphere will generally indicate values clearly after sunset. The sample data were screened and analyzed only on a calm day in order to determine sizes of the UHI phenomenon. Because these weather conditions will prevent formation of the UHI phenomenon (Singhachantra, 2012). After determining the routes to collect sample data, 4 sets of indicators in form of mobile traverses were used, divided into 1 set for outer areas and 3 sets for inner areas. The vehicle speed was controlled not over $40 \mathrm{~km} / \mathrm{h}$ to obtain approximate air temperature data throughout the study area in adjacent periods. Also, the measurement time for each area was determined to be completed within 10-12 minutes. Meanwhile, the time of the indicator for recording data was set every 5 seconds.

\subsubsection{Preparing satellite data}

The data at the closest time of collecting sample data was selected to reduce discrepancies caused by land uses over many different periods of time. The radiation reflectivity and solar height angle of Landsat 8 OLI satellite data (recorded on February 12, 2020 from EarthExplorer-USGS) were adjusted in band 4and 5, according to Equation 1 (Laosuwan et al., 2017; Rotjanakusol \& Laosuwan, 2018).

Where;

$$
\mathrm{P} \lambda=\frac{\mathrm{P} \lambda^{\prime}}{\sin \left(\theta_{\mathrm{SE}}\right)}=\frac{\mathrm{M}_{\mathrm{p}} \mathrm{Q}_{\mathrm{cal}}+\mathrm{A}_{\mathrm{p}}}{\sin \left(\theta_{\mathrm{SE}}\right)}
$$

$\mathrm{P} \lambda=$ Planetary TOA reflectance (unitless)

$M_{p}=$ Reflectance Multi band of band 4 and band 5

$\mathrm{Q}_{\text {cal }}=$ Digital Number (DN) of band 4 and band 5

$\mathrm{A}_{\mathrm{p}}=$ Reflectance add band of band 4 and band 5

$\theta_{\mathrm{SE}}=$ Sun elevation of band 4 and band 5 


\subsection{Data Processing}

\subsubsection{Normalized Difference Vegetation Index (NDVI)}

NDVI is a value indicating the proportion of vegetation that covers the earth's surface. NDVI can be obtained from bringing near infrared wavelength and red visible wavelengths reflected from the earth's surface to calculate the difference of reflections. The values of NDVI will display in the range of -1 and +1 , which can be calculated according to Equation 2 (Ogunode \& Akombelwa, 2017; Rotjanakusol \& Laosuwan, 2019). From Equation 2, it can be explained that the NDVI value approaching 0 means that the area is slightly covered with vegetation. While the NDVI value approaching +1 means that the area is densely covered with vegetation.

$$
\mathrm{NDVI}=\frac{\mathrm{NIR}-\mathrm{RED}}{\mathrm{NIR}+\mathrm{RED}}
$$

Where;

NIR $=$ Reflection in the near-infrared spectrum

$\mathrm{RED}=$ Reflection in the red range of the spectrum

\subsubsection{Measuring atmospheric temperature}

The data from the air temperature measurement and positions were used for spatial interpolation by using ordinary kriging methods to spread the data across the study area and used the equation model for spherical considerations (Al-Mashagbah et al., 2012; Xia et al., 2014; Ruthirako, 2016). The size of the UHI phenomenon in each period could be calculated according to Equation 3 (Oke, 1982; United States. Environmental Protection Agency, 2008; Miles \& Esau, 2017).

$$
\Delta \mathrm{T}=\mathrm{T}_{\mathrm{U}}-\mathrm{T}_{\mathrm{r}}
$$

Where;

$\mathrm{T}_{\mathrm{U}}=$ Average temperature within the boundary of the designated

$\mathrm{T}_{\mathrm{r}}=$ Average temperature of the boundary near the boundary of the boundary of the city according to the outside or the rural area

\subsubsection{Creating buffer zones}

This research created buffer zones at equal distances in every $200 \mathrm{~m}$ in all directions of the study area. The distances were determined away from the boundary in the range of $200-800 \mathrm{~m}$ (Fig. 3 and Table 1), which led to spatial display for analysis of NDVI and UHI sizes in the atmosphere that occurred in each period.

NDVI and UHI sizes in the atmosphere was conducted by determining direction of the relationship of data from correlation coefficient $(r)$ at a significance level of 0.01 , according to Equation 4. This was consistent with the trend line of linear regression equation that led to the acquisition of decision coefficient $\left(\mathrm{r}^{2}\right)$ (Oyler et al., 2016; Liu et al., 2019; Panek, \& Gozdowski, 2019).

Where;

$$
r=\frac{\Sigma\left(\mathrm{X}_{\mathrm{i}}-\overline{\mathrm{X}}\right)\left(\mathrm{Y}_{\mathrm{i}}-\overline{\mathrm{Y}}\right)}{\sqrt{\Sigma\left(\mathrm{X}_{\mathrm{i}}-\overline{\mathrm{X}}\right)^{2} \Sigma\left(\mathrm{Y}_{\mathrm{i}}-\overline{\mathrm{Y}}\right)^{2}}}
$$

The value $r=1$ means a perfect positive correlation and

The value $r=-1$ means a perfect negative correlation. 


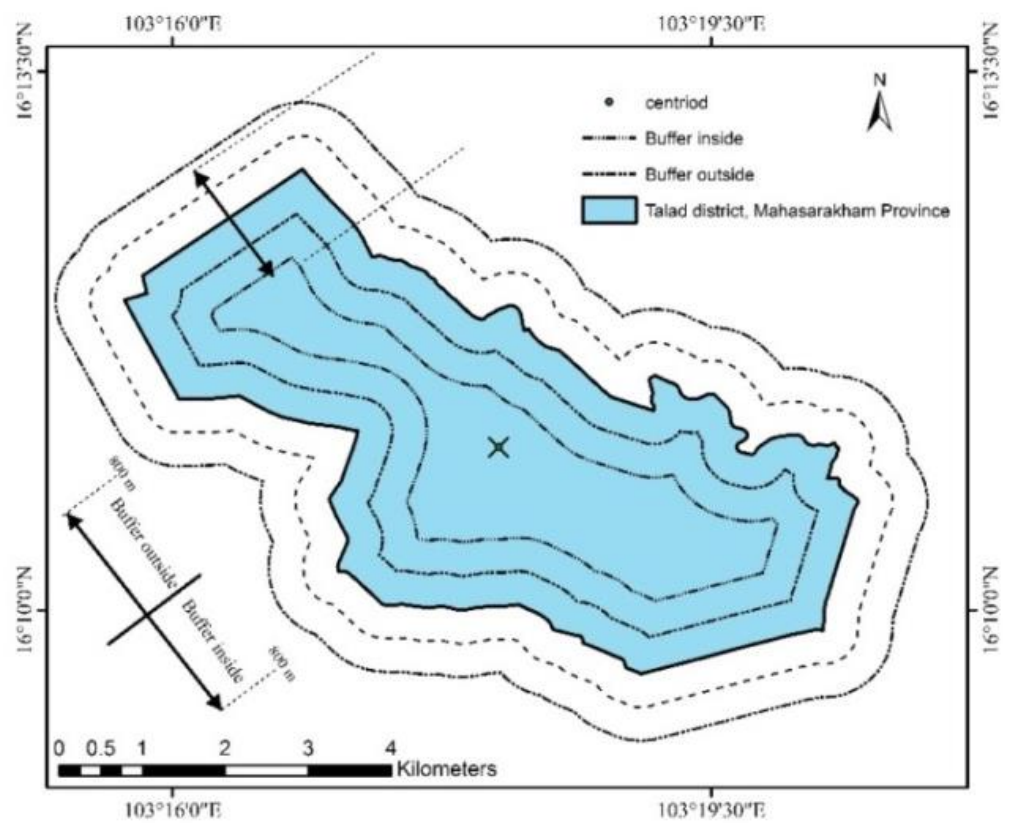

Fig. 3. Illustration boundary areas of collisions based on the boundary of Mueang Maha Sarakham Municipality, each with their common centroid points.

Table 1.

Buffer area.

\begin{tabular}{lcc}
\hline Arbitrary buffer & Distance $(\mathbf{m})$ & Area \\
\hline & 800 & $\left.4 \mathbf{k m}^{2}\right)$ \\
Buffer outside & 600 & 39.65 \\
& 400 & 34.28 \\
& 200 & 29.06 \\
\hline \multirow{3}{*}{ Buffer inside } & 0 & 23.92 \\
& 200 & 19.02 \\
& 400 & 14.64 \\
& 600 & 10.64 \\
& 800 & 7.00 \\
\hline
\end{tabular}

\section{RESULTS AND DISCUSSIONS}

\subsection{Results of NDVI analysis and buffer zones}

The results of NDVI values (Fig. 4 and Table 2) indicated that the rate of vegetation cover tended to decrease from the outer areas to inner areas. This can be remarked that the boundary of Mueang Maha Sarakham Municipality had a dense rate of land uses. 


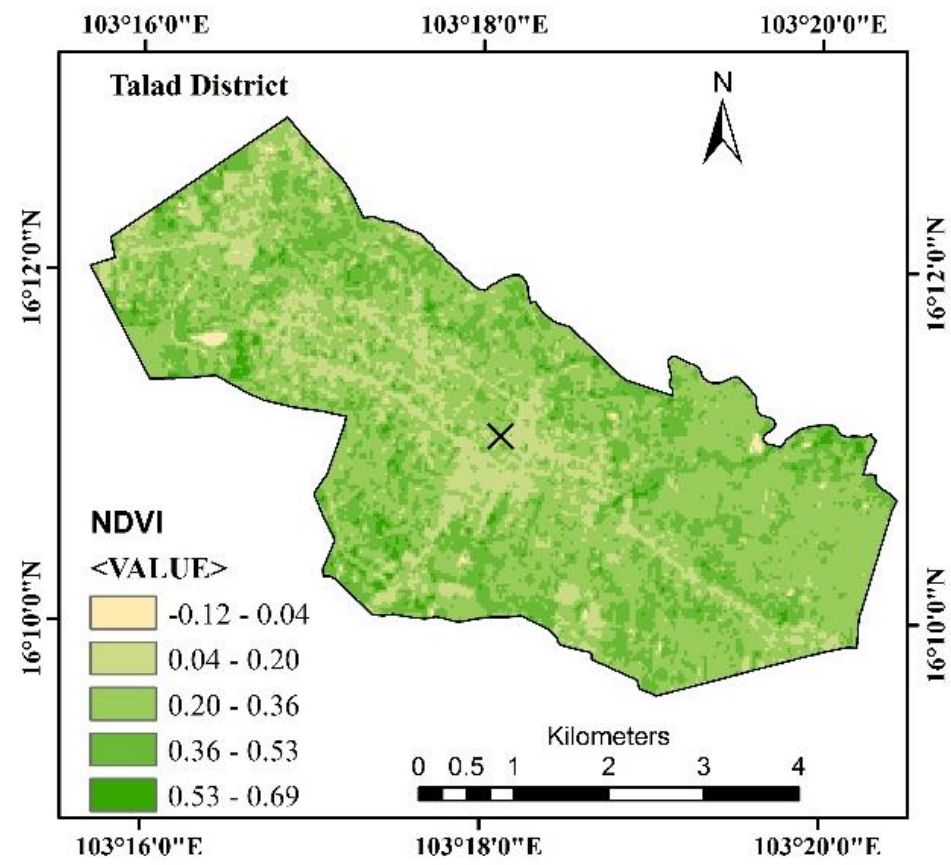

Fig. 4. NDVI covering Mueang Maha Sarakham Municipality.

As a result, the cover of the green spaces was sparse, especially around the centroid point. From determining the boundary for consideration around the centroid point covering an area of $7 \mathrm{~km}^{2}$, it indicated NDVI of 0.28 , which represented the area at the level of low to medium vegetation cover (Taufik et al., 2016; Hashim et al., 2019).

Table 2.

Average of NDVI by buffer area.

\begin{tabular}{cc}
\hline Area $\left(\mathbf{k m}^{\mathbf{2}}\right)$ & NDVI \\
\hline 45.20 & 0.3123 \\
39.65 & 0.3133 \\
34.28 & 0.3139 \\
29.06 & 0.3120 \\
23.92 & 0.3074 \\
19.02 & 0.3026 \\
14.64 & 0.2973 \\
10.64 & 0.2896 \\
7.00 & 0.2801 \\
\hline
\end{tabular}

\subsection{Analysis results of UHI size in the atmosphere}

From the analysis of the difference of air temperatures between inner and outer urban areas at the same time period and spatial interpolation on the atmospheric temperatures from the sample group using the ordinary kriging technique, the expansion of atmospheric temperature in Mueang Maha Sarakham Municipality area was shown in Fig. 5 and Fig. 6. 


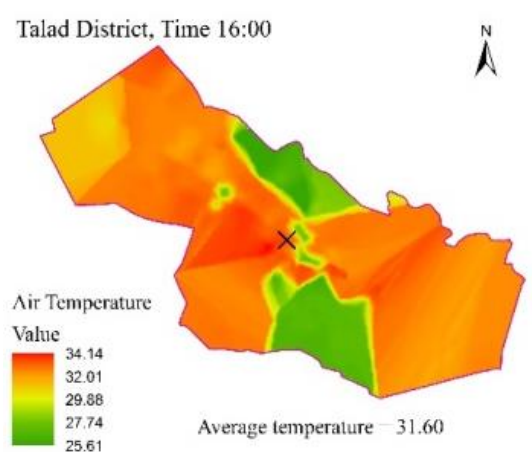

(a)

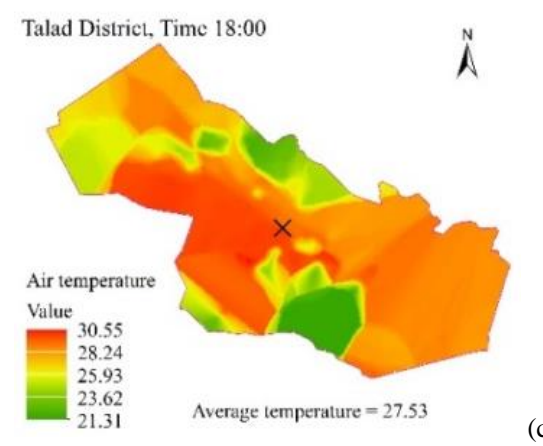

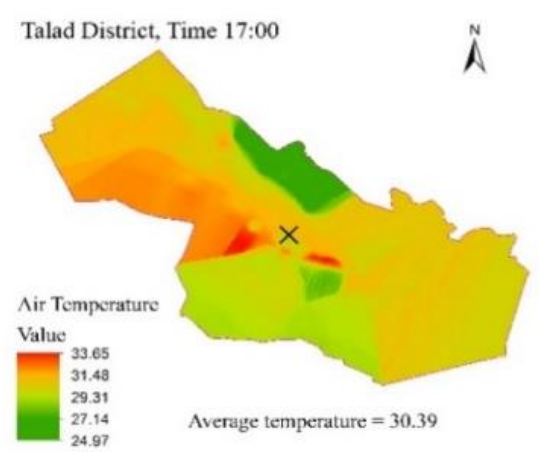

(b)

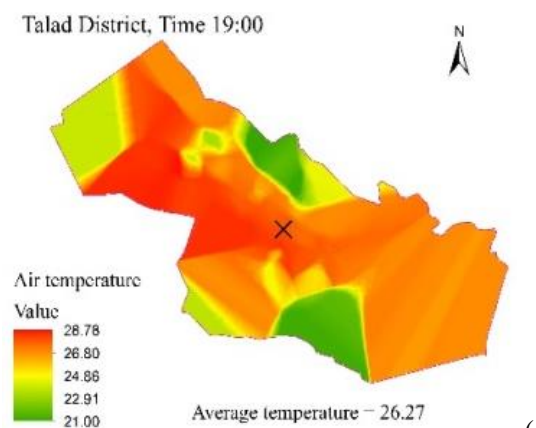

(d)

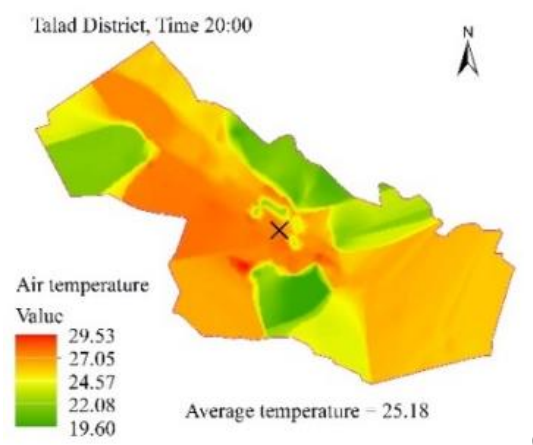

(e)

Fig. 5. Atmospheric temperature in Mueang Maha Sarakham Municipality.

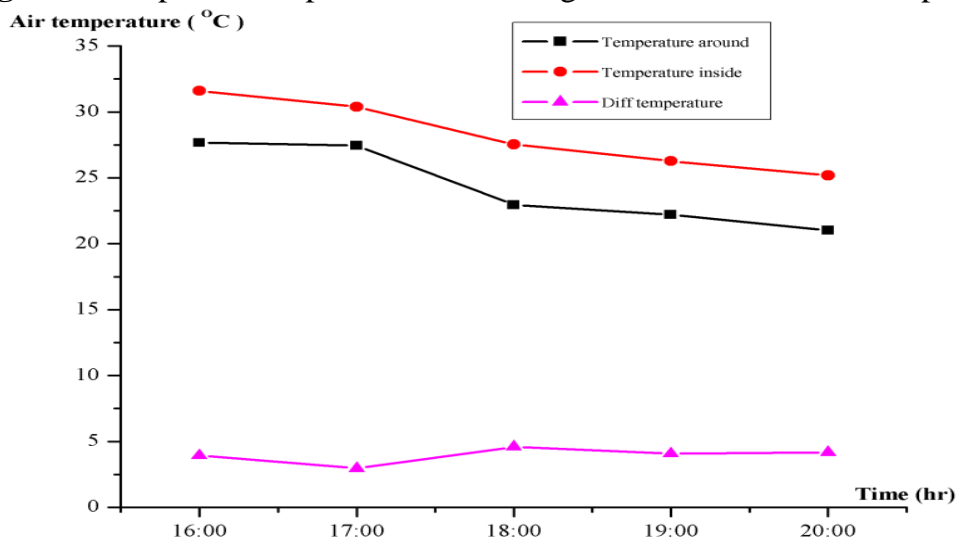

Fig. 6. The trend of changes in the average temperature of each period and the size of the $\mathrm{UHI}$ in the atmosphere. 
The temperatures in both areas tended to decrease after $17.00 \mathrm{hrs}$. The outer areas clearly showed the decrease rate of air temperature clearly while the inner areas of the study area still showed higher average air temperature. In addition, during 17.00 - $18.00 \mathrm{hrs}$., the air temperature in the outer areas changed about $4.5^{\circ} \mathrm{C}$ while the inner areas decreased by $2.8^{\circ} \mathrm{C}$. From the graph, the largest UHI size in the most atmosphere was at $4.58^{\circ} \mathrm{C}$ during $18.00 \mathrm{hrs}$. The UHI size was still high during $200 . \mathrm{hrs}$. with the rate reduced less than $1^{\circ} \mathrm{C}$, while the outer areas of the study area indicated the decrease rate of temperatures by approximately $2^{\circ} \mathrm{C}$.

\subsection{The relationship between NDVI according to the buffer zones and UHI sizes in the atmosphere}

The relationship between NDVI according to the buffer zones and the UHI size in the atmosphere can be shown in Fig. 7, Fig. 8 and Table 3. The graph in Fig.7 shows the change of the UHI sizes in the atmosphere along the buffer line areas. It was found that every time period tended to be in the same direction, which represented the negative relationship between data at a significance level of 0.01 and relatively high correlation coefficient $(r)$ and decision coefficient $\left(r^{2}\right)$.

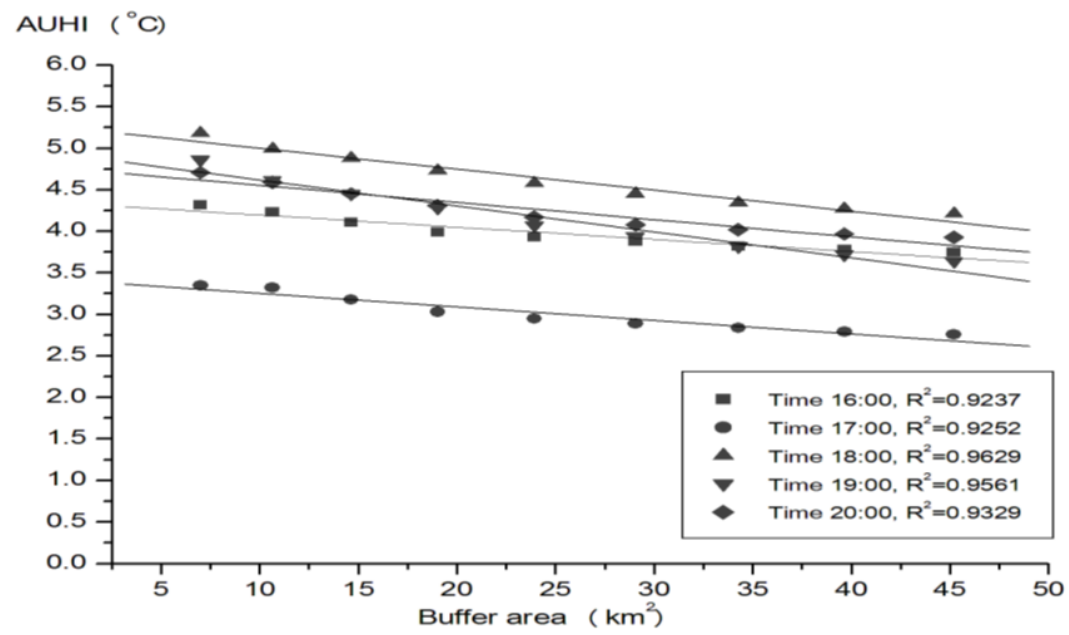

Fig. 7. UHI size in each area of the buffer line areas.

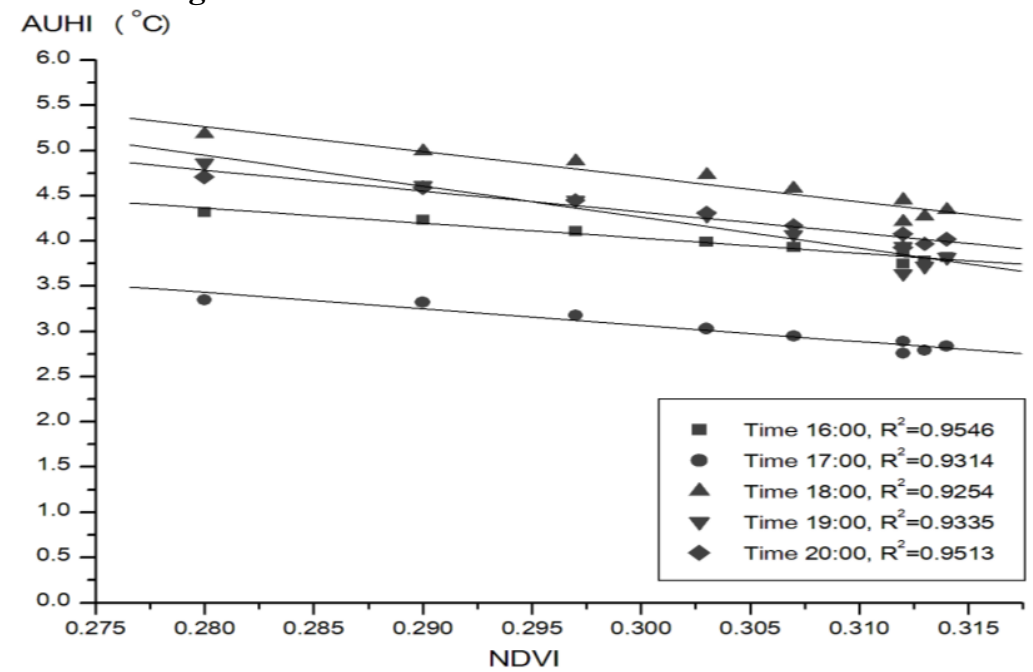

Fig. 8. Decision coefficient from every period. 
The average linear regression equations from all time periods were equal to -0.9696 and 0.9402 , respectively. Also, when the rate of vegetation decreased along the buffer zone, it caused the higher air temperature that resulted in larger UHI size in the atmosphere as well.

The average correlation coefficient $(r)$ and decision coefficient $\left(r^{2}\right)$ from every period of the graph in figure 8 were equal to -0.9691 and 0.9392 , respectively. While considering the period with the largest UHI size and the linear regression equation $\mathrm{Y}=5.25331-0.02529 * \mathrm{X}$ and $\mathrm{Y}_{1}=12.97746$ $27.55394 * \mathrm{X}_{1}$, when the boundary around the centroid point covered the smallest area of $7 \mathrm{~km}^{2}$, it was found that the UHI size in the atmosphere was $5.08^{\circ} \mathrm{C}$ and NDVI was .0 .286 At the same time period, the areas in Mueang Maha Sarakham Municipality indicated UHI and NDVI values of $4.65^{\circ} \mathrm{C}$ and 0.302 , respectively. From the regression equation in the relationship between UHI sizes and the buffer zones, if the distance to the centroid point was determined at $0.001 \mathrm{~km}^{2}$ (very small compared to the size of the whole study area or approaching zero) during $18.00 \mathrm{hrs}$., the maximum heat point indicated at $5.25^{\circ} \mathrm{C}$. From the survey of reflection of the electromagnetic wave for checking existence of vegetation (Fig. 4), it was found that the values in the pixel covered the same coordinates represented NDVI value of 0.16 , which means that there was very little vegetation cover in such the pixel.

In this research, considering in the concept of ideology, if the boundary of Mueang Maha Sarakham Municipality was covered with dense vegetation in the whole area, the tendency of the air temperature in the area was close to the surrounding area, which did not show UHI clearly. However, if the area has the increase in land uses, it will cause the change in air temperature. From the linear regression equation set $\left(Y_{1}=b_{1}+a_{1} X_{1}\right)$, it was found that if Mueang Maha Sarakham Municipality area has developed and expanded structures for the whole area, it will cause the decrease of vegetation cover gradually until completely. And if the existence of vegetation and water resources in the area was equal to zero $\left(\mathrm{X}_{1}=0\right)$, the difference in air temperatures approximately $18.00 \mathrm{hrs}$. was equal to $12.98^{\circ} \mathrm{C}$ and increased to the highest air temperatures approximately $19.00 \mathrm{hrs}$. at $14.55^{\circ} \mathrm{C}$. After that, the air temperatures began to decrease until it reached equilibrium onwards. This indicated that NDVI that tended to decrease in the study area caused the increase in air temperature in urban areas. Also, the time period that showed the largest UHI size would change. In addition, this research had tested the trend of UHI changes in urban areas during 16.00 - $20.00 \mathrm{hrs}$. from the linear regression equation set $\left(\mathrm{Y}_{1}=\mathrm{b}_{1}+\mathrm{a}_{1} \mathrm{X}_{1}\right)$ in case that the study area had decreased NDVI.

Linear regression equation.

Table 3.

\begin{tabular}{ccccc}
\hline Period & $\begin{array}{c}\text { UHI size in each area } \\
\text { of the buffer line areas } \\
\mathbf{Y}=\mathbf{b}+\mathbf{a X}\end{array}$ & $\begin{array}{c}\text { Standard } \\
\text { deviation }\end{array}$ & $\begin{array}{c}\text { UHI size with NDVI } \\
\text { in each area } \\
\mathbf{Y}_{\mathbf{1}}=\mathbf{b}_{\mathbf{1}}+\mathbf{a}_{\mathbf{1}} \mathbf{X}_{\mathbf{1}}\end{array}$ & $\begin{array}{c}\text { Standard } \\
\text { deviation }\end{array}$ \\
\hline $16: 00$ & $\mathrm{Y}=4.34307-0.01467 * \mathrm{X}$ & 0.05962 & $\mathrm{Y}_{1}=9.00329-16.57611 * \mathrm{X}_{1}$ & 0.04599 \\
\hline $17: 00$ & $\mathrm{Y}=3.41526-0.01624 * \mathrm{X}$ & 0.06529 & $\mathrm{Y}_{1}=8.50039-18.10612 * \mathrm{X}_{1}$ & 0.06252 \\
\hline $18: 00$ & $\mathrm{Y}=5.25331-0.02529 * \mathrm{X}$ & 0.07013 & $\mathrm{Y}_{1}=12.97746-27.55394 * \mathrm{X}_{1}$ & 0.09951 \\
\hline $19: 00$ & $\mathrm{Y}=4.92949-0.03122 * \mathrm{X}$ & 0.09456 & $\mathrm{Y}_{1}=14.5475-34.28796 * \mathrm{X}_{1}$ & 0.11645 \\
\hline $20: 00$ & $\mathrm{Y}=4.76042-0.02065 * \mathrm{X}$ & 0.07829 & $\mathrm{Y}_{1}=11.2732-23.17772 * \mathrm{X}_{1}$ & 0.06672 \\
\hline
\end{tabular}

The graph in figure 9 represents the best polynomial regression trend line in the form of the fourth power of the UHI size in the atmosphere in each time period with unequal NDVI values. The results showed that the maximum UHI formation was found between $18.00-19.00 \mathrm{hrs}$. The trend of the decrease in vegetation will result in the increase in UHI size in each period. And when the NDVI value in the area of Mueang Maha Sarakham Municipality was less than 0.30, it can be seen the time period which represented the change of the largest UHI size in the atmosphere, which was likely to approach the period of $19.00 \mathrm{hrs}$. 


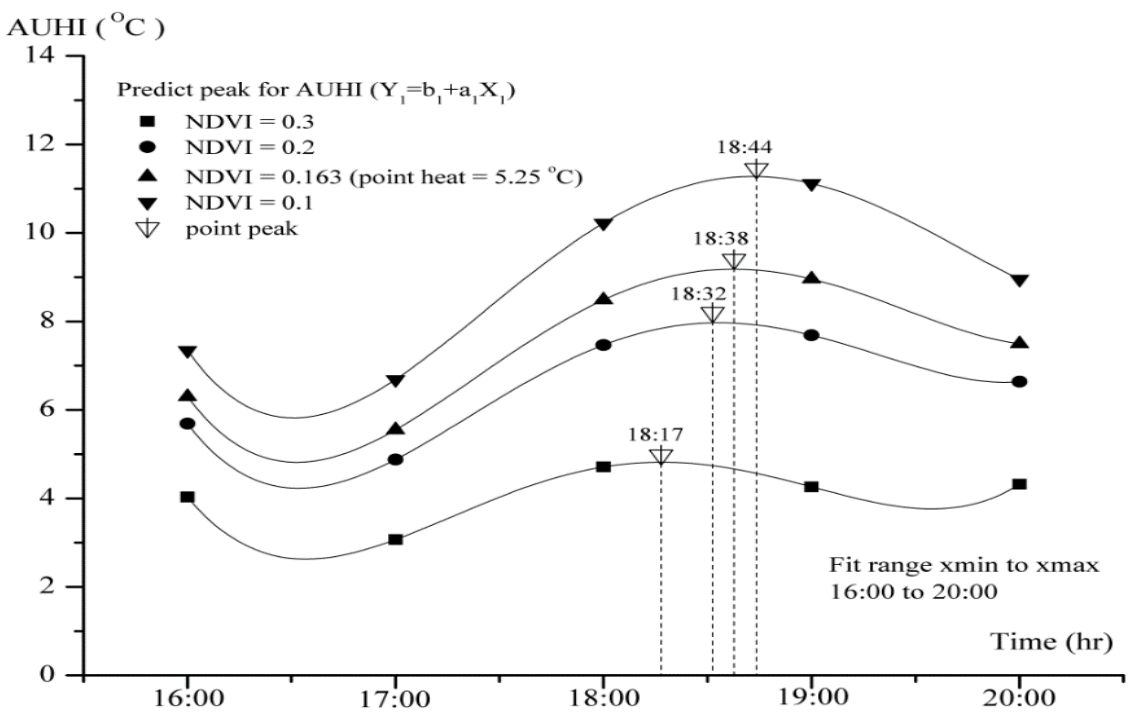

Fig. 9. Polynomial quartic function trend of UHI size change between $16.00 \mathrm{hrs}$ to $20.00 \mathrm{hrs}$ in Mueang Maha Sarakham Municipality when NDVI decreased

\section{CONCLUSIONS}

The study of air temperatures in the area of Mueang Maha Sarakham Municipality could be found as follows: Throughout the period of 16.00-20.00 hrs., the air temperatures inside the study area tended to be higher than the outer area, which had more dense vegetation cover than the inner area that helped decrease the air temperature. While the area within Mueang Maha Sarakham Municipality showed a slight decrease in temperature, especially in the most inner area of the buffer zone. Therefore, the largest UHI size was displayed in the atmosphere during $18.00 \mathrm{hrs}$. The trend of air temperature changes in both areas and UHI sizes occurred were in accordance with the study. The relationship of the UHI phenomenon in each buffer zone towards the study area represented the decrease of NDVI that resulted in the increasing trend of air temperature in each area. From the linear regression relationship, it was found that the area of Mueang Maha Sarakham Municipality had the largest UHI size in the atmosphere at $4.65^{\circ} \mathrm{C}$ and the boundary around the centroid point covering a minimum area of $7 \mathrm{~km}^{2}$ was equal to $5.08^{\circ} \mathrm{C}$.

From the correlation of data between UHI sizes and NDVI values in each buffer zone, all time periods tended to be in the same direction, which represented a negative relationship and obtained the average coefficient of decision $\left(\mathrm{r}^{2}\right)$ from every time period at 0.9392 . The decrease of NDVI caused the difference in air temperatures in urban areas and surrounding areas. From the prediction of difference in air temperatures by using linear regression equation set in Mueang Maha Sarakham Municipality, it was found that UHI sizes at all time periods increased in accordance with the decrease in NDVI values. Meanwhile, when considering the trend of changes in UHI values in the atmosphere with polynomial regression (degree 4), it represented the highest formation rate of UHI during 18.00 - 19.00 hrs. In other words, if each buffer zone had reduced NDVI values or approaching zero, it will obtain the time period that represents the difference in highest air temperature with a tendency of approaching the period of $19.00 \mathrm{hrs}$.

\section{ACKNOWLEDGEMENTS}

This research was financially supported by Mahasarakham University (Grant year 2021). 


\section{R E F E R E N C E S}

Al-Mashagbah, A., Al-Adamat, R. \& Salameh, E. (2012). The use of Kriging Techniques with in GIS Environment to Investigate Groundwater Quality in the Amman-Zarqa Basin/Jordan. Research Journal of Environmental and Earth Sciences. 4(2), 177-185.

Buttstadt, M., Sachsen, T., Ketzler, G., Merbitz, H. \& Schneider, C. (2011). A new approach for highly resolved air temperature measurements in urban areas. Atmos. Meas. Tech. Discuss. 4, 1001-1019.

Cardoso, R.S., \& Amorim, M.C.C.T. (2018). Urban heat island analysis using the 'local climate zone' scheme in Presidente Prudente, Brazil. Investigaciones Geográficas, 69, 107-118.

Dupont, S., \& Ching, J. (2004). Implementation of an Urban Canopy Parameterization in a Mesoscale Meteorological Model. Journal of Applied Meteorology. 43(11), 1648-1665.

Grover, A., \& Singh, R.B. (2015) . Analysis of Urban Heat Island (UHI) in Relation to Normalized Difference Vegetation Index (NDVI): A Comparative Study of Delhi and Mumbai. Environments, 2, 125-138.

Gopal, S., \& Kaufmann, R. (2000). Spatial Interpolation of Surface Air Temperatures Using Artificial Neural Networks: Evaluating Their Use for Downscaling GCMs. Journal of Climate, 13,886-895.

Hashim, H., Abd Latif, Z. \& Adnan, A.N. (2019) .Urban Vegetation Classification with NDVI Threshold Value Method with Very High Resolution (VHR) Pleiades Imagery. Remote Sensing and Spatial Information Sciences, Volume XLII-/4W16, 237-240.

Huang, Q., \& Lu, Y. (2017). Urban heat island research from 1991 to 2015: a bibliometric analysis. Theoretical and Applied Climatology, 131, 1055-1067.

IPCC .(2019). An IPCC Special Report on climate change, desertification, land degradation, sustainable land management, food security, and greenhouse gas fluxes in terrestrial ecosystems (ISBN 978-92-9169-1548) Retrieved from https://www.ipcc.ch/site/ assets/uploads/sites//02/2020/4SPM_Updated-Jan.20pdf

Kambi, M., Wang, Z., \& Gulemvuga, G. (2018). Determination of the Correlation between the Air Temperature Measured in Situ and Remotely Sensed Data from MODIS and SEVIRI in Congo-Brazzaville Atmospheric and Climate Sciences, 8(2), 192-211.

Kaplan, G., Avdan, U., \& Avdan, Z.Y. (2018). Urban Heat Island Analysis Using the Landsat 8 Satellite Data: A Case Study in Skopje, Macedonia. Proceedings of The 2nd International Electronic Conference on Remote Sensing, 2(7), 1-5.

Kophim, W. (2013). Impacts of Land Use and Land Cover Toward Surface Urban Heat Island in Bangkok Metropolitan. (Master of Science). Mahanakorn University, Bangkok.

Liu, H., Zhou, Q., Zhang, S., \& Deng, X. (2019). Estimation of Summer Air Temperature over China Using Himawari-8 AHI and Numerical Weather Prediction Data. Advances in Meteorology. Article ID 2385310, 10 pages. Retrieved from https://doi.org/10.1155/2019/2385310

Li, X., Zhou, W., \& Ouyang, Z. (2013). Relationship between land surface temperature and spatial pattern of greenspace: What are the effects of spatial resolution?. Landscape and Urban Planning. 114, 1-8.

Laosuwan, T., Gomasathit, T., \& Rotjanakusol, T. (2017). Application of Remote Sensing for Temperature Monitoring: The Technique for Land Surface Temperature Analysis. Journal of Ecological Engineering, 18 (3), 53-60.

Mathew, A., Khandelwal, S., \& Kaul, N. (2017). Investigating spatial and seasonal variations of urban heat island effect over Jaipur city and its relationship with vegetation, urbanization and elevation parameters. Sustainable Cities and Society, 35, 157-177.

Miles, V., \& Esau, I. (2017). Seasonal and Spatial Characteristics of Urban Heat Islands (UHIs) in NorthernWest Siberian Cities. Remote sensing, 9(10), 1-15.

Mukhelif, A., Al.Ammar, K., \& Al.Jooburi, M. (2016). The Seasonal Variation of the Urban Heat Island Effect and Estimating the Human - Discomfort Index at the City of Hillah. Pure and Applied Sciences, 24(2), 423434.

Official Statistics Registration Systems. (2019). Number of citizens of Thailand. Retrieved from http://stat. bora.dopa.go.th/stat/pk/pk_62.pdf

Ogunode, A., \& Akombelwa, M. (2017). An algorithm to retrieve Land Surface Temperature using Landsat-8 Dataset. South African Journal of Geomatics, 6(2), 262-276.

Oyler, J.W., Dobrowski, Z.A., Holden, Z.A. and Running, S. (2016). Remotely Sensed Land Skin Temperature as a Spatial Predictor of Air Temperature across the Conterminous United States. Journal of Applied Meteorology and Climatology, 55(7), 1441-1457.

Oke, T. R., (1982). The energetic basis of the urban heat island. Quart. J. R. Met. Soc. 108, 1-24. 
Panek, E., \& Gozdowski, D. (2019). Analysis of relationship between cereal yield and NDVI for selected regions of Central Europe based on MODIS satellite data. Remote Sensing Applications: Society and Environment, 17, 1-11.

Perini, K., \& Magliocco, A. (2014). Effects of vegetation, urban density, building height, and atmospheric conditions on local temperatures and thermal comfort. Urban Forestry \& Urban Greening, 13(3), 495-506.

Rotjanakusol, T., \& Laosuwan, T. (2018). Estimation of Land Surface Temperature using Landsat Satellite Data: A Case Study of Mueang Maha Sarakham District, Maha Sarakham Province, Thailand for the Years 2006 and 2015. Scientific Review Engineering and Environmental Sciences, 27 (4),401-409.

Rotjanakusol,T., \& Laosuwan, T. (2019). An Investigation of Drought around Chi Watershed during Ten-year Period using Terra/modis Data. Geographia Technica, 14(2), 74-83.

Ruthirako, P. (2016). Application of Geo-information Technology to Study Urban Heat Island Phenomenon. SDU Research Journal, 9(3), 147-163.

Sharifi, E., \& Soltani, A. (2017). Patterns of Urban Heat Island Effect in Adelaide: A Mobile Traverse Experiment. Modern Applied Science, 11(4), 80-90.

Sodoudi, S., Shahmohamadi, P., Vollack, K., Cubasch, U., \& Che-Ani, A.I. (2014). Mitigating the Urban Heat Island Effect in Megacity Tehran. Advances in Meteorology. Advances in Meteorology. Article ID 547974, $19 \mathrm{p}$.

Singhachantra, B. (2012). Analysis of the Relation Between Land Covers and Urban Heat Island in Chiang Mai Municipal Area. (Master of Engineering). Chiang Mai University, Chiang Mai.

Srivanit, M., \& Hokao, K. (2012). Thermal Infrared Remote Sensing for Urban Climate and Environmental Studies: An Application for the City of Bangkok, Thailand. Journal of Architectural/Planning Research and Studies, 9(1), 83-100.

Thai Meteorological Department. (2019). Weather summary (monthly). Retrieved from http://www.climate. tmd.go.th/content/category/file

Taufik, A., Ahmad, S., \& Ahmad, A. (2016). Classification of Landsat 8 Satellite Data Using NDVI Thresholds. Journal of Telecommunication, Electronic and Computer Engineering, 8, 37-40.

Takebayashi, H., \& Moriyama, M. (2009). Study on the urban heat island mitigation effect achieved by converting to grass-covered parking. Solar Energy, 83(8), 1211-1223.

United States. Environmental Protection Agency. (2008). Urban Heat Island Basics. In U.S. Environmental Protection Agency (Eds.), Reducing urban heat islands: Compendium of strategies (1st., pp. 1-16) Retrieved from https://www.epa.gov/heat-islands/heat-island-compendium

Ursu, C. (2019). The Land Surface Temperature Evolution (LST) using Landsat Scenes. Case Study: The Industrial Platform Săvineşti, Geographia Technica, 14(2), 131-142.

Vicente-Serrano, S., Cuadrat-Prats, J., \& Saz-Sánchez, M. (2005). Spatial patterns of the urban heat island in Zaragoza (Spain). Climate Research, 30, 61-69.

Xia, B., Ren, Z., \& Koh, C.S. (2014). An Adaptive Optimization Algorithm Based on Kriging Interpolation with Spherical Model and its Application to Optimal Design of Switched Reluctance Motor. J Electr Eng Technol, 9(5), 1544-1550.

Yang, Y., Zhang, X., Lu, X., Hu, J., Pan, X., Zhu Q., \& Su, W. (2018). Effects of Building Design Elements on Residential Thermal Environment. Sustainability, 10(1), 1-15.

Yokobori, T., \& Ohta, S. (2009). Effect of land cover on air temperatures involved in the development of an intra-urban heat island. Climate Research, 39, 61-73.

Zhang, X.X., Wu, P.F., \& Chen, B. (2010). Relationship between vegetation greenness and urban heat island effect in Beijing City of China. Procedia Environmental Sciences, 2, 1438-1450. 